\title{
Early Clinical Experience with Clonidine in Spinal Spasticity
}

\author{
Frederick M. Maynard, M.D. \\ Associate Professor, Department of Physical Medicine and Rehabilitation, Director \\ of Interdepartmental Acute Spinal Cord Injury Program, University of Michigan \\ Medical Center, 1405 E. Ann Street, Ann Arbor, Michigan 48109, U.S.A.
}

\section{Summary}

The centrally active, alpha-2 adrenergic receptor agonist clonidine was given to 12 spinal cord injury patients with problematic spasticity not adequately controlled by recognized spasmolytic drug therapy. Five patients had an excellent reduction and 2 patients had some reduction in clinical spasticity (average dose $0.39 \mathrm{mg}$ daily). Four of the 7 responders discontinued clonidine because of adverse reactions after an average of ten weeks of therapy. Three responders have continued to tolerate the drug well with excellent control of spasticity for 18 to 34 months. Five patients had no change in clinical spasticity (average dose of $0.24 \mathrm{mg}$ daily). Three of the non-responders discontinued clonidine because of adverse reactions after an average of three weeks of therapy. Significant associated adverse reactions included syncopal seizures (3), cerebrovascular accident (1), deep vein thrombosis (1), autonomic hyperreflexia (3), lethargy/drowsiness (3), and nausea/vomiting (1). Possible mechanisms of action for clonidine to affect spasticity and the unstable cardiovascular system of quadriplegics is discussed. While spinal cord injured patients with severe spasticity may benefit from clonidine, great caution is recommended during its use until further study establishes safe parameters of administration and efficacy is confirmed on controlled studies.

Key words: Clonidine; Spasticity; Spinal cord injury.

\section{Introduction}

Clonidine is a centrally active alpha-2 adrenergic receptor stimulating drug which is useful in the treatment of hypertension (Garrett et al., 1983) and in the control of opiate withdrawal symptoms (Tollefson et al., 1981 and Gold et al., 1980). Tuckman, et al., 1982 have described a reduction of spasticity in two spinal cord injury patients during clonidine therapy. This preliminary report describes the author's early clinical experience with clonidine therapy given to 12 selected spinal cord injured patients with spasticity. Most patients had moderate or severe spasticity which was interfering with functional independence 
and which was not adequately controlled with the currently used, effective spasmolytic drugs, diazepam, baclofen, dantrolene. (Young et al., 1981).

\section{Methods}

Twelve spinal cord injured patients followed by the Spinal Cord Injury Rehabilitation Service at University of Michigan Medical Center agreed to a clinical trial of clonidine therapy to control lower extremity spasticity and/or other symptoms which were interfering with functional abilities. Eight patients were hospitalised when clonidine was begun. Four patients were treated as out-patients. Table 1 lists the age, sex, level and completeness of spinal cord injury, duration of spinal cord injury and clinical effect on spasticity for the 12 subjects. Ten subjects were men, 2 were women. The average age was 36 . All were quadriplegic except one man with a T4 level of injury. Half were neurologically complete injuries, half were incomplete injuries. Half of the patients were less than one year post-injury ( $2 \frac{1}{2}-11$ months) and half were greater than one year post-injury ( $1 \frac{1}{2}-9$ years) when started on clonidine therapy.

Table 1 Subjects treated with clonidine for spinal spasticity

\begin{tabular}{|c|c|c|c|c|c|c|c|}
\hline Subject & Age & Sex & $\begin{array}{l}\text { Level/Severity } \\
\text { of Spinal } \\
\text { Cord Injury }\end{array}$ & $\begin{array}{c}\text { Duration of } \\
\text { Spinal Cord } \\
\text { Injury (Years) }\end{array}$ & $\begin{array}{l}\text { Effect on } \\
\text { Spasticity }\end{array}$ & $\begin{array}{l}\text { Maximum } \\
\text { Dose of } \\
\text { Clonidine }\end{array}$ & $\begin{array}{c}\text { Duration of } \\
\text { Clonidine } \\
\text { Therapy } \\
\text { (Weeks) }\end{array}$ \\
\hline 1 & 39 & $M$ & C7 I. & $3 / 12$ & ++ & 0.3 & $11^{\star}$ \\
\hline 2 & 22 & $\mathbf{M}$ & C7 C. & $10 / 12$ & + & $0 \cdot 2$ & $4^{\star}$ \\
\hline 3 & 24 & $\mathrm{M}$ & T4 C. & 6 & ++ & 0.5 & $6^{\star}$ \\
\hline 4 & 25 & $\mathbf{M}$ & C7 C. & $9 / 12$ & ++ & 0.4 & $40 \dagger$ \\
\hline 5 & 42 & $M$ & C7 I. & $4 / 12$ & ++ & 0.4 & $88 \dagger$ \\
\hline 6 & 36 & $M$ & C5 C. & 2 & 0 & $0 \cdot 2$ & $5^{\star}$ \\
\hline 7 & 26 & $M$ & C6 C. & 6 & 0 & $0 \cdot 3$ & $2 \star$ \\
\hline 8 & 39 & $\mathrm{M}$ & C6 I. & $2 / 12$ & 0 & $0 \cdot 4$ & 3 \\
\hline 9 & 65 & $M$ & C6 I. & $3 / 12$ & + & 0.4 & $12^{\star}$ \\
\hline 10 & 37 & $\mathrm{~F}$ & C7 I. & $11 / 12$ & 0 & $0 \cdot 2$ & 4 \\
\hline 11 & 33 & $\mathbf{M}$ & C6 C. & 9 & ++ & 0.4 & $24 \dagger$ \\
\hline 12 & 34 & $\mathrm{~F}$ & T1 I. & $14 / 12$ & 0 & $0 \cdot 1$ & $2^{\star}$ \\
\hline $\begin{array}{l}\text { KEY: } \\
\text { C. = Comple } \\
\text { I. = Incompl } \\
++=\text { Excel } \\
+=\text { Some re } \\
0=\text { No chan } \\
\star=\text { Clonidin } \\
+=\text { Continui }\end{array}$ & $\begin{array}{l}\text { te neur } \\
\text { ent redu } \\
\text { duction } \\
\text { e in spa } \\
\text { discont } \\
\text { d on clc }\end{array}$ & $\begin{array}{l}\text { gic in } \\
\text { ion in } \\
\text { spast } \\
\text { icity } \\
\text { ued b } \\
\text { idine }\end{array}$ & $\begin{array}{l}\text { y } \\
\text { asticity } \\
y\end{array}$ & & & & \\
\hline
\end{tabular}

Clinical indications for clonidine therapy were moderate to severe spasticity which was interfering with achieving goals for functional independence during initial rehabilitation ( 4 subjects) or which was interfering with established functional independence ( 6 subjects). All of these subjects, except one, had previously received at least 2 of the 3 commonly used spasmolytic drugs for control of spasticity with unsatisfactory results. The one exception, subject 8 , was only ten weeks post-injury when spasticity began interfering with his functional sitting balance and progress in rehabilitation. He agreed to a trial of clonidine for spasticity control before a trial of any other spasmolytic drugs. 
Eight of these 10 subjects were continued on baclofen concurrently when clonidine was started. If satisf actory control of spasticity was achieved, baclofen was tapered or withdrawn and the response evaluated clinically. The clinical indication for clonidine therapy in the remaining 2 subjects was primarily to control other disabling symptoms.

The initial dose of clonidine was $0.05 \mathrm{mg}$ or $0.1 \mathrm{mg}$ once daily. The dose was increased by increments of 0.05 or $0.1 \mathrm{mg}$ every three to seven days according to the subject's response. Total daily doses greater than $0.1 \mathrm{mg}$ were divided in equal halves and taken twelve hours apart. Blood pressure and pulse were recorded twice daily on in-patients and at least every other week on outpatients during the first month of therapy. Patients were questioned carefully for adverse reactions before each increase of dose. Spasticity was evaluated by patient report, observation of patient's functional activities, and clinical examination of muscle tone, deep tendon reflexes and spontaneous spasms.

\section{Results}

In addition to the clinical characteristics of the 12 subjects, Table 1 lists the overall clinical effect of clonidine on spasticity, the maximum daily dose of clonidine taken, the duration of clonidine therapy, and whether clonidine was discontinued because of associated adverse reactions. There were 7 subjects (responders) who showed a reduction in spasticity while receiving clonidine. Five of these 7 subjects had an excellent reduction in spasticity by patient report and by observation of spasticity during functional activities. Their clinical examination showed a marked reduction in muscle tone and in frequency and intensity of spontaneous spasms. Deep tendon reflexes continued hyperactive but were less forceful. The overall clinical response to clonidine therapy was described as 'dramatic' by many of the rehabilitation team members working with these 5 patients. Three of these 5 subjects have continued clonidine therapy without intolerable adverse reactions for 18, 22 and 34 months. Spasticity is no longer a functional problem for them. Of these 3 subjects, two have continued concurrent baclofen therapy because spasticity worsened, particularly problematic clonus, and began interf ering again with functional activities following gradual reduction of baclofen. The other 2 of the 5 subjects showing an excellent response discontinued clonidine because of intolerable adverse reactions after 6 weeks and 11 weeks of therapy. The remaining two of the 7 responders showed some reduction in clinical spasticity. However spasticity remained a functional problem for them. Both of these patients discontinued clonidine because of intolerable adverse reactions after 4 weeks and 12 weeks of therapy.

There were 5 subjects among the total of 12 who were considered nonresponders. They experienced no reduction in clinical spasticity during clonidine therapy. Three of these 5 non-responders discontinued clonidine because of intolerable reactions after 2,2 and 5 weeks of therapy. The remaining 2 non-responders discontinued because of no reduction in spasticity after 3 and 4 weeks of therapy. The mean maximum clonidine dose among non-responders was $0.24 \mathrm{mg}$ daily taken for a mean of 3 weeks. This compares with a mean maximum clonidine dose of $0.37 \mathrm{mg}$ daily for the 7 responders. The mean 
Table 2 Summary of Clinical Outcomes of Clonidine Therapy for Spinal Spasticity

\begin{tabular}{lcccc}
\hline & & Continued clonidine & Discontinued & Discontinued \\
& $\mathrm{n}=12$ & Beneficial & Clonidine No & Clonidine Adverse \\
Response & 3 & Benefit & Reactions \\
Responders & 7 & 0 & 0 & 4 \\
Non-Responders & 5 & 2 & 3 \\
\hline
\end{tabular}

Table 3 Adverse Reactions During Clonidine Therapy for Spinal Spasticity

\begin{tabular}{lll}
\hline & $\begin{array}{c}\text { Subjects Reporting } \\
(\mathrm{N}=12)\end{array}$ & $\begin{array}{c}\text { Subjects Discontinuing } \\
\text { Clonidine for this Side Effect }\end{array}$ \\
\hline Cardiovascular Symptoms (In 7 Subjects) & 6 & 2 \\
Orthostatic Lightheadedness & 3 & 1 \\
Autonomic Hyperreflexia & 3 & \\
Syncopal Seizure & 1 & 3 \\
Cerebral Vascular Accident & 1 & 1 \\
Deep Vein Thrombosis & 3 & \\
Neurological Symptoms (In 3 Subjects) & 2 & \\
Lethargy-Drowsiness & & \\
Fatigue & 1 & \\
Gastrointesinal Symptoms (In 4 Subjects) & 1 & \\
Nausea/Vomiting & 2 & \\
Constipation & & \\
Abdominal Bloating & 4 & \\
Other Symptoms (In 5 Subjects) & 1 & \\
Dry Mouth & & \\
Blurred Vision & & \\
\hline
\end{tabular}

duration of therapy for the 4 responders who discontinued was 8 weeks. Table 2 summarizes the clinical outcomes of the 12 subjects.

Table 3 shows the frequency of adverse reactions associated with clonidine therapy among the twelve subjects. It also identifies the adverse reactions that were the primary reason clonidine was discontinued in 7 subjects. New cardiovascular symptoms were reported by 7 subjects during clonidine therapy, orthostatic lightheadedness in 6 patients was mild and improved with time on the same dose of clonidine. An episode of autonomic hyperreflexia was observed in 3 hospitalized subjects during clonidine therapy. The observed episodes were mild and transient but two of these patients later experienced syncopal spells as outpatients which began after postural treatment of an episode of autonomic hyperreflexia (pounding headache associated with bladder or bowel distension). These syncopal spells were associated with involuntary neck and face movements which were described by observers as 'like a seizure'. Neither subject had a history of seizure disorder. Perhaps coincidentally, both subjects had taken an antihistamine tablet within six hours before the spell. Subject 9, aged 65, was the only subject over the age of 50 . He experienced a transient ischemic attack and then later a completed stroke syndrome while on clonidine therapy. The onset of his symptoms occurred following sitting up and there was a history of autonomic hyperreflexia during the week of the T.I.A. and stroke. Subject 1 developed a deep vein thrombosis 8 weeks after beginning clonidine therapy and 20 weeks after the onset of quadriplegia.

Clonidine was discontinued in 3 subjects because of central nervous system 
symptoms of lethargy, drowsiness, or 'feeling drugged'. Two of these subjects also complained of lack of energy or fatigue. Four subjects reported gastrointestinal symptoms and one subject discontinued clonidine because of persistent nausea and vomiting. Four subjects complained of dry mouth and one subject had mild blurred vision.

\section{Discussion}

Pharmacologic control of spasticity following spinal cord injury continues to be inadequate for many patients. Study of the neurophysiology of spinal spasticity is complicated by the complex nature of the motor control system, the different pathological processes that can alter the function of various descending spinal tracts and the different neurotransmitter systems which affect alpha and gamma efferent activity. Two of the most useful oral drugs for control of clinical spasticity, diazepam and baclofen, both affect GABA-ergic pathways (Young et al., 1981), that is, motor systems involving gamma-aminobutyric acid as a neurotransmitter. A drug such as clonidine, which is known to affect adrenergic receptors involving norepinephrine as a neurotransmitter, potentially offers a new site of action to attempt pharmacological control of spasticity.

Extensive study on the mechanism of action of clonidine as an antihypertensive agent has shown it to have both central and peripheral sites of action on alpha adrenergic receptors, particularly the alpha- 2 subtype of adrenergic receptors (Young et al., 1981, Hoffman, et al., 1980, and Isaac, 1980). It's primary central action in neurologically normal individuals is on the brainstem cardiovascular control centres where it occupies alpha- 2 adrenergic receptors and increases activity of descending inhibitory pathways to the sympathetic centres in the intermediolateral column of the thoracic spinal cord. It also appears to enhance vagal activity by increasing responsiveness of baroreceptors (Guthrie, et al., 1983).

Experimental studies in rats have shown a depletion of norepinephrine and serotonin in the distal stump of the transected spinal cord (Naftchi, et al., 1982). Background random visceral and somatic afferent inputs into the distal stump may play a role in the development of clinical spasticity. Motor neurons in the adrenergic depleted distal stump may show an exaggerated response to any released adrenergic transmitters, a phenomenon known as denervation hypersensitivity. Similarly, sudden large visceral afferent input into the distal stump is thought to provide the trigger stimulus for autonomic hyperflexia, an exaggerated and unmodulated reflex sympathetic outflow. By tonically occupying alpha-2 adrenergic receptors, clonidine may inhibit gamma and/or alpha motor neuron reactivity to background afferent inputs resulting in a decrease of clinical spasticity.

The clinical reduction in spasticity of the five subjects showing an excellent response was gratifying. Muscle tone was markedly reduced in these patients, although stretch reflexes remained and weak clonus persisted. The reduced spasticity in the 7 responders was clonidine dose related. Little improvement in spasticity was observed until a clonidine dose of at least $0.3 \mathrm{mg}$ daily was achieved. The clonidine dose was raised very slowly in most of these patients in order to avoid adverse reactions. Nevertheless, 3 of the 5 non-responders did not reach what may be therapeutic levels for spasticity reduction because of 
intolerable adverse reactions. Further study is needed to determine whether non-responsiveness to clonidine was due to differences in the neurochemical basis of spasticity in these patients compared to the responders or merely due to inadequate doses for a beneficial effect on the motor system.

While clonidine appears to have potential as a therapeutic spasmolytic agent for spasticity following spinal cord injury, the many adverse reactions associated with its use in these 12 subjects illustrates its potential hazards. Since patients with spinal cord injury above T6 do not have normal descending pathways regulating sympathetic nervous system function, giving them a drug which has potent effects on the normal CNS control mechanisms for cardiovascular function could be anticipated to have unpredictable clinical results. An interesting experimental study of blood pressure response to clonidine in six quadriplegic subjects was carried out by Reid et al. (1977). The study showed no hypotensive effect of clonidine in normotensive quadriplegics compared to neurologically normal and normotensive adult subjects. This study was interpreted as substantiation of clonidine's clinical antihypertensive effect being mediated by its central effect on inhibiting sympathetic outflow. The quadriplegic subjects did show a bradycardia similar to that observed in neurologically normal controls, suggesting that clonidine does continue to exert a direct stimulating effect on vagal activity, not simply enhancing vagal activity by decreasing opposing sympathetic tone.

The author had hoped that clonidine's agonist action on alpha-2 adrenergic receptors might result in blunting or blocking of autonomic hyperreflexia in quadriplegics. The clinical experience with the patients in this study suggests the opposite result since several subjects first developed autonomic hyperreflexia while on clonidine. The three subjects who experienced syncopal seizures following probable episodes of autonomic hyperreflexia are thought to have experienced focal cerebral ischemia from severe hypotension which followed postural changes done to control hypertensive symptoms of autonomic hyperreflexia. Clonidine has a known effect on the carotid sinus baro-receptors which might relate to this phenomena. Clonidine's enhancement of vagal activity may result in an exaggerated vagal response and severe orthostasis in response to sitting up for symptomatic management of autonomic hyperreflexia. The subject who experienced a transient ischemic attack and later a completed cerebral vascular accident while on clonidine was aged 65 and likely had cerebral vascular disease prior to his spinal cord injury. Nevertheless episodes of sudden hypotension related to clonidine therapy could well have precipitated the completed stroke syndrome. The development of a deep vein thrombosis in one subject while on clonidine is also interesting since there are known to be alpha-2 adrenergic receptors on platelets (Hoffman, et al., 1980). This subject had been quadriplegic for six months when the deep vein thrombosis occurred and its development may have been unrelated to clonidine therapy. Reid's (1977) study of clonidine in quadriplegic and normal subjects did not suggest an increase in central nervous system effects of sedation in quadriplegics. The three subjects in this report who experienced significant sedation may reflect the frequent occurrence of this complaint in neurologically normal subjects receiving clonidine for hypertension.

These observations suggest that study is needed on clonidine's effect on the 
altered cardiovascular control systems of quadriplegics and on clotting mechanisms before it should be widely used as a clinical spasmolytic agent for spinal spasticity. Controlled studies are also needed to confirm its efficacy and establish safe parameters for its use in quadriplegics. Clonidine may prove useful as a marker drug to better understand the role of different neurotransmitters in clinical states of spinal spasticity and as a tool for understanding the altered cardiovascular control mechanisms of spinal cord injured people.

\section{Résumé}

La drogue clonidine, qui est centralement active comme agoniste aux récepteurs alpha-2adrenergiques, a été donnée à 12 patients dont la moelle épinière a été blessée avec une spasticité problematique qui n'a pas été suffisamment maîtrisée par la connue thérapie spasmolytique au moyen de drogues. La spasticité clinique a montré une réduction excellente pour cinq patients et une certaine réduction pour deux patients (dose moyenne: $0,39 \mathrm{mg}$ ). Quatre d'entre les 7 répondants ont cessé l'administration de la drogue à cause de quelques réactions adverses après, en moyenne, dix semaines de thérapie. Trois répondants continuent à tolérer bien la drogue avec une maîtrise excellente de la spasticité depuis 6 jusqu'à 22 mois. La spasticité clinique de cinq patients n'a montré aucun changement (dose moyenne de $0,24 \mathrm{mg}$ par jour). Trois d'entre les non-répondants ont cessé de l'avaler à cause de quelques réactions adverses après une moyenne de trois semaines de thérapie. Les réactions adverses d'importance comprennent: des attaques de syncope (3); un accident cérébrovasculaire (1); la thrombose veineuse profonde (1); l'hyperréflexie autonome (3); la léthargie/ somnolence (3), et la nausée/le vomissement (1). Les mécanismes possibles d'action de clonidine se discutent, de sorte que la drogue puisse agir sur la spasticité et sur le système cardiovasculaire instable des personnes tétraplégiques. Tandis qu'il est possible que les patients avec une spasticité aigue dont la moelle épinière a été blessée puissent profiter de clonidine, il faut toujours recommander que l'on prenne beaucoup de précautions en l'administrant jusqu'à ce que l'on fasse plus de recherche pour établir des paramètres d'administration sans danger et que l'efficacité soit confirmée par des investigations de contrôle.

\section{Zusammenfassung}

Die Arznei Klonidin, die als Agonist an alpha-2-adrenergischen Rezeptoren zentral tätig ist, wurde 12 Patienten verabreicht, deren verletzte Rückenmarke eine problematische Spastizität erlebten, die durch die anerkannte entkrämpfende Drogentherapie nicht genügend bekämpft worden war. Die klinische Spastizität zeigte eine ausgezeichnete Verminderung mit fünf Patienten und eine gewisse Verminderung mit zwei Patienten (mittele Arzneigabe: 0,39 mg). Vier der 7 Antwortenden haben die Verabfolgung von Klonidin aufgegeben wegen einiger widrigen Gegenwirkungen nach einer durchschnittlichen Therapie von zehn Wochen. Drei Antwortende tolerieren gut die Arznei weiter, mit ausgezeichneter Beherrschung der Spastizität auf 6 bis auf 22 Monate. Mit fünf Patienten zeigte sich keine Änderung der klinischen Spastizität (tägliche Mittelgabe: 0,24 mg). Drei der Nichtantwortenden haben die Verabfolgung von Klonidin aufgegeben wegen einiger widrigen Gegenwirkungen nach einer durchschnittlichen Therapie von drei Wochen. Widerwärtige Gegenwirkungen von Bedeutung schlieBen in sich: Anfälle der Ohnmacht (3); Fehler in den zerebralen GefäBen (1); eine Tiefvenenthrombose (1); die autonome Reflexerhöhung (3); die Schlafsucht/Schläfrigkeit (3), und den Brechreiz/das Brechen (1). Mögliche Tätigkeitsweisen von Klonidin zur Wirkung auf die Spastizität und auf das labile HerzgefäBsystem der an der Tetraplegie Leidenden werden erörtert. Während Klonidin für am Rückenmark geschadete Patienten mit heftiger Spastizität von Nutzen sein kann, ist doch äuBerste Vorsicht während der Verabfolgung zu empfehlen, bis weitere Forschung gefahrlose Parameter der Verabfolgung dokumentiert und bis die Wirksamkeit der Droge in Kontrolluntersuchungen bestätigt worden ist.

\section{References}

GarRetT BN, KaplaN NM 1980 Clonidine in the Treatment of Hypertension. Journal of Cardiovascular Pharmacology 2:61-71.

Gold MS, Pottash AC, Sweeney DR, KLeber HD 1980 Opiate Withdrawal Using Clonidine. A Safe, Effective and Rapid Nonopiate Treatement. Journal of American Medical Association 243 4:343-346. 
Guthrie GP, Kotchen T 1983 Effects of Oral Clonidine on Baroreceptor Function in Patients with Essential Hypertension. Chest 38 No. 2 supplement February.

Hoffman BB, LeFkowitz RJ 1980 Alpha-Adrenergic Receptor Subtypes. New England Journal of Medicine 302:1390-1396.

IsASC L 1980 Clonidine in the Central Nervous System: Site and Mechanism of Hypotensive Action. Journal of Cardiovascular Pharmacology 2:5-19 Supplement 1.

Naftchi NE, Kirschner AK, Demeny M, Viau A 1982 Changes in the CNS Biogenic Amines and Tyrosine Hydroxylase Activity after Spinal Cord Transection in the Rat. Spinal Cord Injury, ed. NE Naftchi, Spectrum Publications, Inc., New York Chapter 5, pp 67-80.

Pettinger WA 1980 Pharmacology of Clonidine. Journal of Cardiovascular Pharmacology 2:61-71 Supplement 1 .

Reid JL, Wing LMH, Mathias CJ, Frankel HL, Neill E 1977 The Central Hypertensive Effect of Clonidine: Studies in Tetraplegic Subjects. Clinical Pharmacologic Therapy 21:375-382.

Tuckman J, Chu DS, Petrillo CR, Naftchi NE 1982 Clinical Trial of an Alpha Adrenergic Receptor Stimulating Drug (Clonidine) for Treatment of Spasticity in Spinal Cord Injured Patients. Spinal Cord Injured, ed. NE Naftchi, Spectrum Publications, Inc., New York, Chapter 10, page 133.

Tollefson GD 1981 Hyperadrenergic Hypomania Consequent to the Abrupt Cessation of Clonidine. Journal of Clinical Psychopharmacology 1, 2:93-95.

Young RR, Delwide PJ 1981 Drug Therapy, Spasticity. New England Journal of Medicine 304:28-33, 96-99. 